\title{
Different Type Clay Amendments for Lead Immobilization in Contaminated Soils
}

\author{
Juris Burlakovs $^{1}$, Anete Karklina ${ }^{2}$, Andris Karpovics ${ }^{3}$, Maris Klavins ${ }^{4}$ \\ ${ }^{1,2,4}$ University of Latvia, ${ }^{3}$ Riga Technical University
}

\begin{abstract}
Contamination with lead in soil is a crucial problem in industrial and military sites. Immobilization of lead by natural and modified clay as soil amendment can be an effective solution to this problem. Quaternary and Devonian clays were chosen for modification with $\mathrm{NaCl}, \mathrm{CaCl}_{2}, \mathrm{FeOOH}$ and $\mathrm{Ca}_{10}\left(\mathrm{PO}_{4}\right)_{6}(\mathrm{OH})_{2}$ in different proportions of $\mathrm{Ca} / \mathrm{P}$ equimolar ratio to test and compare immobilization efficiency of lead (II) on raw and modified clays by using a batch leaching test. The aim of the study is to compare different types of raw and modified clays as soil amendments by lead immobilization properties.
\end{abstract}

Keywords: Clay modification, hydroxyapatite, immobilization, iron oxyhydroxide, soil amendments.

\section{INTRODUCTION}

Heavy metal pollution including lead is an increasingly urgent problem all over the industrialized world. High heavy metal concentrations in soil and groundwater often are the result of anthropogenic activities, e.g., mining industry and treatment of metal ores, waste incineration, transport and the use of agrochemicals [1]. In the European Union, the number of estimated contaminated sites varies from 0.3-1.5 million by different approaches [2]. According to the European Commission $\sim 3-5$ million potentially contaminated and 0.5 million contaminated sites are mentioned. The latter need remediation activities [3].

After World War II more than 1000 units of Soviet Army forces were located in about 600 military sites that covered $\sim 10 \%$ of Latvia's territory. The largest firing grounds were Zvārde, Liepāja Navy port (Karaosta), Rudbārži missile base and Lielvārde airfield [4]. Contamination with heavy metals, toxic organic compounds, and also with oil products was determined in about 11 military territories. In spite of the remaining historical contamination, some of these territories are readjusted for the use of another purpose, e.g., the area of Riga Freeport [5].

Heavy metals are very toxic because as ions or in compound forms they are soluble in water and may be readily absorbed into living organisms. After absorption, these metals can bind to vital cellular components such as structural proteins, enzymes, and nucleic acids, and interfere with their functions. In humans, some of these metals, even in small amounts, can cause severe physiological and health effects [6]. Global release of trace elements as pollutants into the environment may be correlated with the mineral and energy consumption. Lead is one of the most common heavy metal as anthropogenic pollutant [7]. The natural $\mathrm{Pb}$ content in soil originates from parent rocks and overall mean value of $\mathrm{Pb}$ for different soils has been calculated to be, on the average, at $25 \mathrm{mg} \mathrm{kg}^{-1}$, but unpolluted soil $\mathrm{Pb}$ concentration as being less than $100 \mathrm{mg} \mathrm{kg}^{-1}$ [8]. Lead in soil shows good correlation with its content in fine granulometric fraction. Its lowest amount up to $40 \mathrm{mg} \mathrm{kg}^{-1}$ can be found in light sandy soil whereas the highest up to $90 \mathrm{mg} \mathrm{kg}$ - in heavy loamy soil. Some increased $\mathrm{Pb}$ contents have been reported for calcareous and organic soils. Lead is not distributed uniformly in soil and reveals great association with $\mathrm{Fe}$ and $\mathrm{Mn}$ hydroxides. Its concentrations in Fe-Mn nodules may be very high and reach up to $20,000 \mathrm{mg} \mathrm{kg}^{-1}$. [9] Mobility of $\mathrm{Pb}$ is slow and its concentration in solution is relatively low - depending on methods used for obtaining soil solution those vary from $<1$ $60 \mu \mathrm{g} \mathrm{L}^{-1}$. It occurs in soil solution as cationic species: $\mathrm{Pb}^{2+}$, $\mathrm{PbCl}^{+}, \mathrm{PbOH}^{+}$, as well as anionic species: $\mathrm{PbCl}_{3}{ }^{-}, \mathrm{Pb}\left(\mathrm{CO}_{3}\right)_{2}{ }^{2-}$ [10]. Lead desorbed into the soil solution may easily move from the upper horizons to lower and result in the pollution of groundwater. Some authors have emphasized that the $\mathrm{Pb}$ fixation by soil organic matter is more important than fixation by hydrous oxides [11]. It is not known exactly how much of the soil lead is available to plants; Davies [12] reported that only about $0.005-0.13 \%$ of $\mathrm{Pb}$ in the soil solution is available to plants. Uptake of lead by plants depends on soil properties, such as soil organic matter peculiarities, granulometric composition, cation exchange capacity (CEC), $\mathrm{pH}$, as well as root surface area and exudates [13].

Among various natural and anthropogenic sources of $\mathrm{Pb}$ contamination, the impact of industrial emissions and previously used leaded petrol is considered to be of the largest environmental risk. It has been evaluated that $\mathrm{Pb}$ loading rate in soil exceeds its natural removal by 20 -fold or more [14]. Important sources of $\mathrm{Pb}$ in home-garden soils are $\mathrm{Pb}$ containing paints. The geometric mean of $\mathrm{Pb}$ in such soils of the United Kingdom was calculated at $298 \mathrm{mg} \mathrm{kg}^{-1}$ [15]. The $\mathrm{Pb}$ contamination of roadside soils has been a real environmental concern for quite a long time period. Though $\mathrm{Pb}$ additives in petrol are banned in most countries, increased $\mathrm{Pb}$ levels in soil along high traffic road (up to $7,000 \mathrm{mg} \mathrm{kg}^{-1}$ ) are still observed [8]. Tetraethyl- and tetramethyl- $\mathrm{Pb}$ can be converted into sparingly water-soluble $\mathrm{Pb}$ compounds in soil, but, laboratory tests have indicated that those do not leach significantly through soil profile [16].

Leaching from contaminated soil with Devonian Lode raw clay amendment in Latvia has been already studied for copper [17]. The aim of the study is to compare different types of raw and modified clays as soil amendments by lead immobilization properties. Improvement of soil by using soil amendments, e.g., modified clay, can be an innovative solution in remediation industry. Batch leaching tests are appropriate for evaluation of heavy metal immobilization efficiency of innovative soil amendments. 


\section{MATERIALS AND METHODS}

Soil Samples for Leaching Experiments. Three different soils were chosen for spiking with lead nitrate solution. Mineral soil samples were collected during geotechnical field works from different depths (3-12 m) nearby the Daugava estuary in the floodplain area in order to have typical soil which often is contaminated in industrial and former military sites (Table I).

TABLE I

PARAMETERS OF THREE DIFFERENT SOIL SAMPLES FOR SPIKING WITH LEAD NitRATE SOLUTION

\begin{tabular}{|l|c|c|c|}
\hline Parameters / Soil & 1 & 2 & 3 \\
\hline Sand $(\%)$ & 93.7 & 20.4 & 91.6 \\
\hline Silt $(\%)$ & 6.3 & 79.6 & 8.4 \\
\hline Clay $(\%)$ & 0.0 & 0.0 & 0.0 \\
\hline $\mathrm{pH}_{\mathrm{KCl}}$ & 4.0 & 6.9 & 8.0 \\
\hline $\mathrm{Na}\left(\mathrm{mg} \mathrm{kg}^{-1}\right)$ & 186 & 193 & 186 \\
\hline $\mathrm{Mg}\left(\mathrm{mg} \mathrm{kg}^{-1}\right)$ & 80 & 153 & 70 \\
\hline $\mathrm{K}\left(\mathrm{mg} \mathrm{kg}^{-1}\right)$ & 15.3 & 28.5 & 22.2 \\
\hline $\mathrm{Ca}\left(\mathrm{mg} \mathrm{kg}^{-1}\right)$ & 397 & 1046 & 903 \\
\hline $\mathrm{CEC}\left(\mathrm{mmol} \mathrm{g}^{-1}\right)$ & 0.004 & 0.009 & 0.007 \\
\hline Organics $(\%)$ & 0.44 & 0.64 & 0.03 \\
\hline
\end{tabular}

Samples of clay for testing as soil amendments from three clay deposits in Latvia were taken - Sātini, Lielauce and Lode quarries, Zellu Lake and Borovichi quarry in Russia, Novgorod Oblast. All samples were taken from different depths (1-6 m) with a hand auger.

Lielauce Quaternary clay deposit is located in southwestern Latvia. The thickness of deposit productive layer is between 1.1 and $5.3 \mathrm{~m}$. Those are mostly illitic clays with amount of clayey fraction $(<0.005 \mathrm{~mm})$ varying between 36 and $43 \%$ [18].

Sātini Quaternary clay deposit is located in south-western Latvia. The thickness of deposit productive layer lays between 1.1 and $7.8 \mathrm{~m}$. Clays consist mostly of illite and chlorite with significant amount of calcite $(\sim 16 \%)$, amount of clayey fraction $(<0.005 \mathrm{~mm})$ varies between 69 and $82 \%$ [19].

Lode Devonian clay deposit is located in north-eastern part of Latvia. Deposit consists of upper Devonian, Gauja Formation clastic sediments. There are two types of clay - red, variegated silty clay, and grey thick clay. It is mostly illitic clay with kaolinite and chlorite [20].

Borovichi varved clay was taken from quarry in the Russian Federation, Novgorod Oblast, Zellı Lake clay - from eastern part of Latvia not far from the border with Russia. These samples were chosen as typical Quaternary varved clays, which can be found in glaciolacustrine sediments of Late Pleistocene glacial lakes.

Air-dried soil samples (Table I) were sieved through a 2-mm sieve and fractions finer than $0.05 \mathrm{~mm}$ were determined by pipette analysis [21]. On the basis of the USDA soil texture classes, the fractions from 0.063 to $2.0 \mathrm{~mm}$ were classified as sand, those from 0.002 to $0.063 \mathrm{~mm}$ were classified as silt, and those finer than $0.002 \mathrm{~mm}$ were classified as clay [22] (Table I). The percentage of sand, silt and clay was calculated from fine earth $\left(<2 \mathrm{~mm}\right.$ fraction). Soil $\mathrm{pH}_{\mathrm{KCl}}$ was measured with a glass electrode in $1 \mathrm{M} \mathrm{KCl} \mathrm{(1:2.5} \mathrm{mass-to-volume} \mathrm{ratio)}$ in triplicate.

For the determination of the soil cation exchange capacity (CEC) the $0.1 \mathrm{M} \mathrm{BaCl}_{2}$ (Sigma-Aldrich, analytical grade) was used, samples were batch treated, filtrated and elements analyzed by atomic absorption spectrometry (AAS) by PerkinElmer Instrument Analyst 200. In order to find out total organic carbon (TOC) amount, Shimadzu TOC-VCS $S_{N}$ TOC analysator with solid phase detection module SSM-5000A was used. Granulometric parameters are given in Table I, as well as other properties for the $\mathrm{pH}(\mathrm{KCl})$, macro-components, organic content and CEC.

Soil samples (Table I) were spiked with lead nitrate in order to apply known contamination of $100 \mathrm{mg} \mathrm{kg}^{-1}$ and kept for a week in order to fix the lead contamination. Spiked soils were prepared for 14 sets of leaching experiment with the use of different soil amendments (Fig. 1, Table II).

Soil Amendments. In order to compare the efficiency of natural and modified clays as contaminated soil amendments different clays were chosen. Devonian Lode and Quaternary Lielauce raw clay were tested to gain CEC by using methylene blue method [23]. Results have shown 0.05 and $0.10 \mathrm{mmol} \mathrm{g}^{-1}$ respectively. Calculated volume of $2.5 \mathrm{mmol} \mathrm{L}^{-1}$ methylene blue was added to $0.3 \mathrm{~g}$ of clay, obtained suspensions were shaken for $24 \mathrm{~h}$ at $200 \mathrm{rpm}$ (Biosan Multi Shaker PSU-20), then centrifuged (Biosan LMC-300) at 2500rpm for $30 \mathrm{~min}$. The changes in methylene blue concentration after sorption were detected with Jenway 6300 spectrometer $(1=1 \mathrm{~cm}$, $\mathrm{A}=\mathrm{ebc} ; \lambda=664 \mathrm{~nm}$ ). Modification of both types of clay was done by iron oxide-hydroxide, hydroxyapatite, $\mathrm{Ca}$ and Na salts (Table II). Sātini clay, Zellu Lake clay and Borovichi clay were not modified - those were used as amendments to spiked soil as raw clay.

Modification of Quaternary Lielauce Clay with Fe OxideHydroxide. Clay was modified by iron oxide-hydroxide. For $\mathrm{Fe}(\mathrm{OH})_{3}$ preparation, $250 \mathrm{~mL}$ of $0.25 \mathrm{M}$ and $0.5 \mathrm{M} \mathrm{FeCl}_{3} \cdot 6 \mathrm{H}_{2} \mathrm{O}$ were amended with $250 \mathrm{~mL}$ of $3 \mathrm{M} \mathrm{NaOH}$ for three hours (all Sigma Aldrich, analytical grade). Washing and decanting were repeated three times and $100 \mathrm{~g}$ of clay were mixed in $\mathrm{Fe}(\mathrm{OH})_{3}$ dispersion. Mixing, filtration and washing with deionised water were repeated, the drying for $12 \mathrm{~h}$ was done in a room temperature, at the end the drying was fulfilled in Gallenkamp Plus II oven for $4 \mathrm{~h}$ in the temperature of $60^{\circ} \mathrm{C}$.

Modification of Devonian Lode Clay with Ca and Na Salts was carried out in two ways $-5 \mathrm{~g}$ of clay were added in $500 \mathrm{~mL}$ of $0.5 \mathrm{M} \mathrm{CaCl}_{2}$, other $-5 \mathrm{~g}$ of sorbent were added in $500 \mathrm{~mL}$ of $0.5 \mathrm{M} \mathrm{NaCl}$ (all Sigma Aldrich, analytical grade) and stirred for 24h, afterwards 3 times decanted and washed with D/I water. Modified clays were dried in Gallenkamp Plus II oven at the temperature of $45^{\circ} \mathrm{C}$ for $8 \mathrm{~h}$.

Modification of Quaternary Lielauce Clay with Hydroxyapatite. $8 \mathrm{~g}$ of clay were mixed with $30 \mathrm{~mL}$ of distilled water and $10 \mathrm{~mL}$ of $0.5 \mathrm{M} \mathrm{CaCl}_{2}$, afterwards the mixture was left for $12 \mathrm{~h}$ for swelling. Four different concentrations were calculated in order to get accurate equimolar proportions of $\mathrm{Ca} / \mathrm{P}$ when (equimolar) $\mathrm{KH}_{2} \mathrm{PO}_{4}$ was added to get $1.6,1.3,1.0$ and 0.5 proportions. Proportion of 1.6 is more corresponding to hydroxyapatite, 0.5 for monetite. $\mathrm{pH}$ values for reactions 
were determined in all cases 9.0 with the use of $0.2 \mathrm{M} \mathrm{NH}_{4} \mathrm{OH}$ (all reagents from Sigma Aldrich, analytical grade), after $12 \mathrm{~h}$ decanting, washing with $\mathrm{D} / \mathrm{I}$ water was done until neutral conditions for solutions were achieved. Ethanol for final removal of unnecessary salts was used and substance was dried in Gallenkamp Plus II oven at the temperature of $105^{\circ} \mathrm{C}$ until liquid was evaporated.

Soil Amendment Addition to Spiked Soil. 13 sets of amendment testing for each of three soil samples were done by adding $10 \%$ of different amendments: unmodified 1) Quaternary Sātiņi quarry clay, 2) Zel̦lu lake clay, 3) Borovichi varved clay, modified - 4-7) Quaternary Lielauce clay modified in 4 different $\mathrm{Ca} / \mathrm{P}$ equimolar proportions, 8 9) modified with $5 \% \mathrm{FeOOH}$ and $10 \% \mathrm{FeOOH}$ respectively, 10-11) unmodified Devonian red and grey-blue clay, 1213) Devonian modified with $\mathrm{Ca}$ and $\mathrm{Na}$ salts respectively. 14) One test for spiked soil with no amendment was performed in order to see the difference (Table II). Four sets of additional experiments were performed by various amount of amended clay - for this purpose $1 \%, 5 \%, 10 \%$ and $25 \%$ of dry mass of Quaternary Sātiņi raw clay varied (Fig. 2).

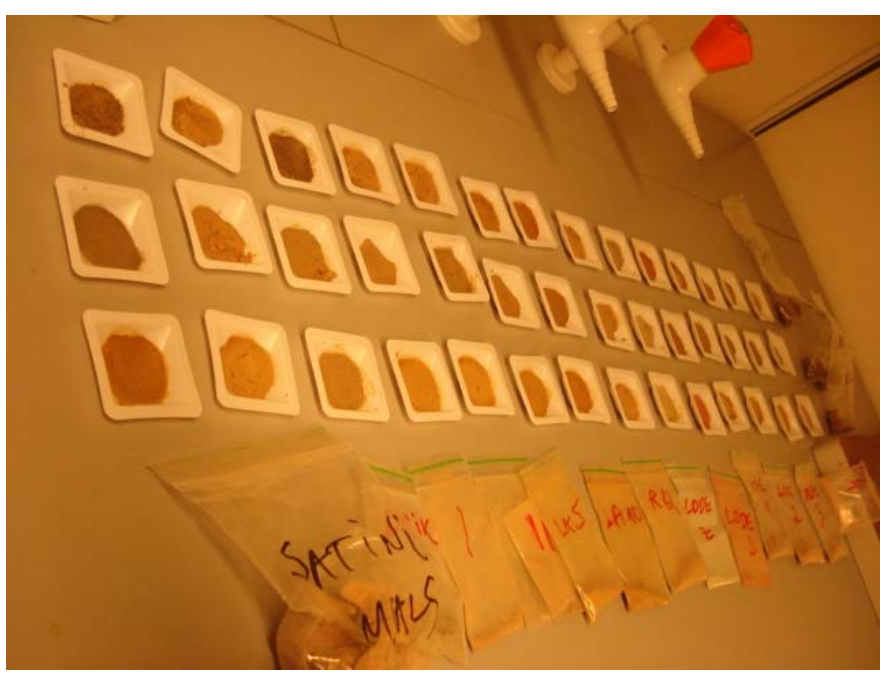

Fig. 1. Spiked soils (3 different types in Table I) with amendments (13 different clays and 1 with no amendment in Table II) prepared for leaching tests at Linnaeus University laboratory.

Leaching Tests. During the batch leaching test vessels were filled with distilled water till a liquid-to-solid-ratio 10:1 (referred to the dry sample). Under continuous agitation at the rate of 130rpm (Grant OLS200) the batch leaching test was done for samples with the shaking time period of $24 \mathrm{~h}$. $\mathrm{pH}_{\mathrm{H} 2 \mathrm{O}}$ level was measured for all samples before and after by using Beckmann $\mathrm{pH}$ meter 340. After this time the solution was set down for about 10 minutes. For the determination of lead content, the solution was filtered through a $0.45 \mu \mathrm{m}$ filter. The concentration of $\mathrm{Pb}$ in the leached eluate was determined by AAS (GBC 932 Plus, Perkin Elmer) with deuterium background correction and a spectral slit width of $0.5 \mathrm{~nm}$ for $\mathrm{Pb}$ and $\lambda=283.31 \mathrm{~nm}$. All leaching experiments were performed at the Laboratory of Environmental Chemistry at Linnaeus University in Kalmar.

\section{RESULTS AND DISCUSSION}

Leaching Experiment Results. Experiments were performed in order to find good suited soil amendment material (clay) to spiked soils in order to immobilize lead contamination.

The $\mathrm{pH}_{\mathrm{H} 2 \mathrm{O}}$ values of samples were mostly of natural neutral conditions 4.6-6.5 and during the $24 \mathrm{~h}$ agitation $\mathrm{pH}_{\mathrm{H} 2 \mathrm{O}}$ for eluates were not significantly changing. Table II depicts results of leaching from different soils (3 types) with different amendments applied to each (13 types +1 no amendment). Soil sample No. 2 with higher content of silty $(79.6 \%)$ particles diminishes the leaching of lead itself even with no clay amendment. Sātini clay amendment increase (from 1\% up to $25 \%$ of dry mass) shows larger immobilization of lead in spiked soils (Fig. 2). All the clay amendments (No. 1-13 in Table II) show lead immobilization efficiency, but most efficient ones are clays modified with $\mathrm{Ca}$, $\mathrm{Na}$ salts and hydroxiapatite. Good efficiency is reached by application of FeOOH modified clays for immobilization of lead. Less efficient but still significant clay can be reached if Quaternary natural unmodified clay from Sātini quarry is amended. Unmodified Devonian Lode clay as well as natural Borovichi and Zellu Lake clay decreases leaching of lead from pure sandy soil, but efficiency is not satisfactory.

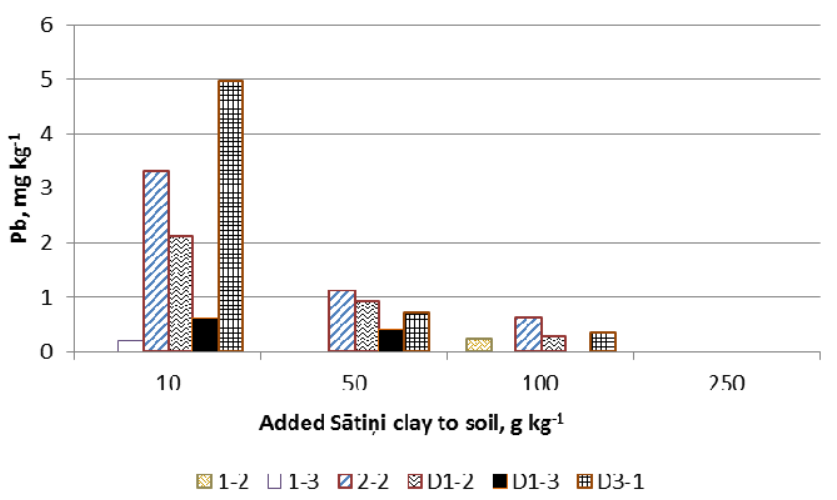

Fig. 2. Lead sorption from spiked soils amended with raw Sātinii quarry clay (1, 5,10 and $25 \%$ of dry mass). Texture of original spiked soils are of sandy content (for D3-1 and 2-2 >90\%), other samples (70-90\%).

Figure 2 shows quantitative differences for the leaching of lead if raw Sātini clay is amended in different amounts. The quantitative amount of lead leached from soil is significantly decreasing if $5 \%$ of clay is added. If larger amount of clay amendment is added (10\%), it plays a less significant role. $25 \%$ of clay amendment immobilizes all of contamination in the given concentration of $100 \mathrm{mg} \mathrm{kg}^{-1}$.

General results show that lead ions are better immobilized if modified clay is added to soil; also if more clay is added quantitatively, thus proving general trends that lead ion immobilization is better in soils with higher CEC. Immobilization of heavy metals in contaminated soil in situ by using clay as amendment is an effective method for diminishing environmental hazards with low and average target concentrations and relatively stable environment. Clay is a well-known immobilizing agent for heavy metal contaminants and most effective results for lead immobilization were achieved by using as soil amendment the Lielauce quarry clay modified by hydroxiapatite and Ca salts. 
TABLE II

LEACHING EXPERIMENT RESULTS FOR SPIKED SOILS (100 MG KG $\left.{ }^{-1}\right)$ AMENDED WITH VARIOUS CLAy AMENDMENTS*

\begin{tabular}{|c|c|c|c|c|c|}
\hline $\begin{array}{c}\text { Experimental set: type of amendment ( } 10 \% \text { of dry } \\
\text { sample mass added) }\end{array}$ & $\begin{array}{c}\mathrm{pH}_{\mathrm{KCl}} \\
\text { start value } \\
\text { (soils } 1 / 2 / 3 \text { ) }\end{array}$ & $\begin{array}{c}\mathrm{pH}_{\mathrm{H} 2 \mathrm{O}} \\
\text { end value } \\
\text { (soils } 1 / 2 / 3 \text { ) }\end{array}$ & $\begin{array}{c}\text { Soil No. } 1 \\
\left(\mathrm{mg} \mathrm{kg}^{-1} \text { leached }\right. \\
\text { lead })\end{array}$ & 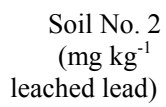 & $\begin{array}{c}\text { Soil No. } 3 \\
\text { (mg kg-1 leached } \\
\text { lead) }\end{array}$ \\
\hline 1) Quaternary Sātiņi quarry clay $10 \%$ & 4.6/4.9/4.7 & 4.8/4.9/4.9 & 2.77 & 0.17 & 2.67 \\
\hline 2) Zellıu Lake clay & $5.7 / 5.7 / 5.8$ & $5.7 / 5.9 / 5.6$ & 40.2 & 0.38 & 36.8 \\
\hline 3) Borovichi varved clay & $5.2 / 5.7 / 5.4$ & $5.1 / 5.9 / 5.6$ & 29.3 & 0.26 & 24.8 \\
\hline $\begin{array}{l}\text { 4) Quaternary Lielauce clay modified in } 1.6 \mathrm{Ca} / \mathrm{P} \\
\text { equimolar proportion (hydroxiapatite) }\end{array}$ & $5.9 / 6.2 / 5.8$ & $6.4 / 6.5 / 6.3$ & 0.10 & $<0.02$ & $<0.02$ \\
\hline $\begin{array}{l}\text { 5) Quaternary Lielauce clay modified in } 1.3 \mathrm{Ca} / \mathrm{P} \\
\text { equimolar proportion }\end{array}$ & $5.5 / 6.2 / 6.0$ & $6.2 / 6.2 / 6.1$ & $<0.02$ & 0.08 & $<0.02$ \\
\hline $\begin{array}{l}\text { 6) Quaternary Lielauce clay modified in } 1.0 \mathrm{Ca} / \mathrm{P} \\
\text { equimolar proportion }\end{array}$ & $5.3 / 5.4 / 5.2$ & $5.8 / 5.9 / 5.8$ & $<0.02$ & $<0.02$ & $<0.02$ \\
\hline $\begin{array}{l}\text { 7) Quaternary Lielauce clay modified in } 0.5 \mathrm{Ca} / \mathrm{P} \\
\text { equimolar proportion (monetite) }\end{array}$ & $5.4 / 5.3 / 5.2$ & $5.5 / 6.0 / 5.4$ & $<0.02$ & $<0.02$ & $<0.02$ \\
\hline $\begin{array}{l}\text { 8) Quaternary Lielauce clay modified with } \\
5 \% \mathrm{FeOOH}\end{array}$ & $5.2 / 5.1 / 5.3$ & $5.4 / 5.6 / 5.3$ & 0.45 & 0.39 & 0.40 \\
\hline $\begin{array}{l}\text { 9) Quaternary Lielauce clay modified with } \\
10 \% \mathrm{FeOOH}\end{array}$ & $5.7 / 5.7 / 5.6$ & $5.8 / 5.7 / 5.7$ & 0.49 & 0.36 & 0.33 \\
\hline 10) unmodified Devonian Lode red clay & $4.8 / 5.2 / 5.1$ & $5.1 / 5.2 / 5.0$ & 32.3 & $<0.02$ & 39.7 \\
\hline 11) unmodified Devonian Lode grey-blue clay & $4.6 / 5.1 / 5.0$ & $4.9 / 5.4 / 5.3$ & 42.1 & 0.06 & 39.2 \\
\hline 12) Devonian modified with Ca salt & $5.5 / 6.0 / 5.7$ & $5.9 / 6.2 / 6.1$ & $<0.02$ & $<0.02$ & $<0.02$ \\
\hline 13) Devonian modified with Na salt & $5.0 / 5.3 / 5.0$ & $5.2 / 5.5 / 5.2$ & 0.04 & $<0.02$ & 0.03 \\
\hline 14) no amendment to spiked soils & $4.8 / 5.1 / 4.7$ & $4.9 / 5.0 / 4.7$ & 54.2 & 2.15 & 52.7 \\
\hline
\end{tabular}

* - leaching mass loss from filtered soil samples found in eluates were measured in units $\mathrm{mg} \mathrm{L}^{-1}$, but in Table I they are given recalculated with rate $\mathrm{L}: \mathrm{S}$ 10:1 and therefore they are given for comparison also in $\mathrm{m} \mathrm{kg} \mathrm{k}^{-1}$ by arithmetically multiplying with 10 . Standard deviation for AAS values varies in the range of $0.89-8.9 \%$

\section{CONCLUSIONS}

A series of leaching tests were performed in order to test lead immobilization properties for various types of raw and modified with $\mathrm{FeOOH}, \mathrm{Ca}$ and $\mathrm{Na}$ salts and hydroxiapatite clays. Leaching tests showed a minor effect of unmodified Devonian Lode and Quaternary Borovichi and Zellu Lake clays on soil treatment contaminated with lead. Leaching tests proved that most effective results for lead immobilization were achieved by using as soil amendment the Lielauce quarry clay modified by hydroxiapatite and $\mathrm{Ca}$ salts. Immobilization of lead was manifold; thus, the feasibility of modified local Latvian Quaternary clay from Sātini and Lielauce as well as Lode quarries should be studied further to determine economic advantages of such a type of remediation compared to other techniques.

\section{ACKNOWLEDGEMENTS}

The research has been carried out with the help of European Social Fund (ESF), Linnaeus University in Kalmar and the Faculty of Chemistry at the University of Latvia. Special thanks are expressed to Dr. Amit Bhatnagar and Doctoral Student Jūija Karasa for the advice concerning laboratory work.

\section{REFERENCES}

[1] Lado, L.R., Hengl, T., Reuter, H.I. Heavy metals in European soils: a geostatistical analysis of the FOREGS Geochemical database. Geoderma, 2008, 148, p. 189-199. http://dx.doi.org/10.1016/j.geoderma.2008.09.020
[2] "9VAC20-160-10. Definitions", Virginia Register Volume 13, Issue 18, eff. June 26, 1997; amended, Virginia Register Volume 18, Issue 18, eff. July 1，2002， http://leg1.state.va.us/cgi-bin/legp504.exe?000+reg+ 9VAC20-160-10. accessed: 01.10.2012.

[3] Vanheusden, B. "Recent development in European policy regarding brownfield remediation", Environmental Practice, 11 (4), 2009, p. 256262. http://dx.doi.org/10.1017/S1466046609990202

[4] National Register of Contaminated and Potentially Contaminated Sites in Latvia (in Latvian: Piesārņoto un potenciāli piesārņoto vietu regístrs LR), http://oas.vdc.lv:7779/p ppv.html, accessed: 15.08.2013.

[5] Burlakovs, J., Vircavs, M. Possible Applications of Soil Remediation Technologies in Latvia, RTU Zinātniskie raksti, Vides un klimata tehnologijas. 2011, 7. sēj., p. 46-53.

[6] Wayne, G. L., Ming-Ho, Yu. Introduction to Environmental Toxicology: Impacts of Chemicals Upon Ecological Systems, 2003, Boca Raton: Lewis Publishers, $512 \mathrm{p}$.

[7] Angelone, M., Bini, C. Trace elements concentration in soils and plants of Western Europe. In: Adriano, D.C. (ed) Biogeochemistry of trace metals. Lewis Publ, Boca Raton, 1992, p. 19-60.

[8] Kabata-Pendias, A., Pendias, H. Trace elements in soils and plants. 4th ed. 2010, 331 p. http://dx.doi.org/10.1201/b10158

[9] Merian, E., Anke, M, Ihnat, M., Stoepppler, M. (eds) Elements and their compounds in the environment, Wiley-VCH, Weinheim, 2nd ed., 2004, p. 79-99. http://dx.doi.org/10.1002/9783527619634

[10] Kabata-Pendias, A., Mukherjee, A.B. Trace Elements from Soil to Human, 2007, Berlin: Springer-Verlag, 561 p. http://dx.doi.org/10.1007/978-3-540-32714-1

[11] Li, Z., Shuman, L.M. Heavy metal movement in metal contaminated soil profiles. 1996, Soil Sci 161, p. 656-666. http://dx.doi.org/10.1097/00010694-199610000-00003

[12] Davies, B.E. Lead. In: Alloway, B.J. (ed), Heavy metals in soils. 1995, Blackie Academic, London, p. 206-223.

[13] Sillanpää, M., Jansson, H. Status of cadmium, lead, cobalt and selenium in soils and plants of thirty countries. FAO Soils Bull 65, Rome 1992. 
[14] Nriagu, J.O., Pacyna, J.M. Quantitative assessment of worldwide contmiantion of air, water and soils by trace metals. 1988, Nature, 1669, p. 14-139.

[15] Thornton, I. A survey of lead in the British urban environment: an example of research in urban geochemistry. In: Lieth, H., Markert, B. (eds) Element concentration cadaster in ecosystems. 1990, Wiley-VCH, Weinheim, pp 221-240.

[16] Ou, L-T., Jing, W., Thomas, J.E. Biological and chemical degradation of ionic ethyllead compounds in soil. 1995, Environ Toxicol Chem 14, p. 545-551. http://dx.doi.org/10.1002/etc.5620140401

[17] Burlakovs, J., Klavins, M., Karklina, A. Remediation of soil Contamination With Heavy Metals by Zeolite and Humic Acid Additives. Latvian Journal of Chemistry, 2013, Vol. 51, Issue 4, p. 336-341.

[18] National Research Program Nr. 2010.10-4/VPP-5, „Sustainable use of local resources (earth entrails, wood, foodstuffs and transport) - new products and technologies (NatRes)",

http://www.lu.lv/fileadmin/user upload/lu portal/ projekti/vpp/Iegulas/Q/Lielauce.pdf, accessed: 07.06.2013.

[19] National Research Program Nr. 2010.10-4/VPP-5, „Sustainable use of local resources (earth entrails, wood, foodstuffs and transport) - new products and technologies (NatRes)",

http://www.lu.lv/fileadmin/user upload/lu portal/ projekti/vpp/Iegulas/Q/Satini.pdf, accessed: 07.06.2013.

[20] Sleine, H. Overview of detailed investigation of Liepa deposit in Cesis district. (LGF 03533), 1962, Ģeologijas pārvalde, Riga, pp. 1286 (in Russian).

[21] Van Reeuwijk, L.P. Procedures for Soil Analysis. 5th edition, 1995, Wageningen, $101 \mathrm{p}$.

[22] FSCC (Forest Soil Co-Ordinating Centre). Manual IIIa: Sampling and Analysis of Soil. In: ICP Forests: Manual on methods and criteria for harmonized sampling, assessment, monitoring and analysis of the effects of air pollution on forests. UNECE ICP Forests Programme Co-ordinating Centre, Hamburg. 2006, p. 26 with annexes, http://icp-forests.net/page/icpforests-manual, accessed: 07.08.2012.

[23] Sarceviča, I., Actiňš, A. Smectite clay sorption capacity determination (in Latvian: Smektītu mālu sorbcijas kapacitātes noteikšana), 2009, Latvian Journal of Chemistry, Nr.3, 187-196

Juris Burlakovs is a Researcher at the Department of Environmental Sciences at the University of Latvia. Scientific interest is focused on heavy metal contamination remediation technologies in different geoecological conditions.

He received the Master's Degrees in Environmental Management (2009) and Quaternary Geology and Geomorphology (2002) from the University of Latvia. He studied engineering at the University of Padova, Italy and Linnaeus University, Sweden.

$\mathrm{He}$ is a Member of Board of Geo IT Ltd. in Riga. Earlier career is related to geomagnetic research and geology.

$\mathrm{He}$ is a Member of the Latvian Association for Quaternary Research, Latvian Astronomical Society and European Association of Geoscientists and Engineers. Address: Alberta Str. 10, LV-1010, Riga, Latvia

Phone: +371 28469044, E-mail: juris@geo-it.lv

Anete Kārklina is Master's Degree student majoring in Environmental Sciences at the University of Latvia. Her scientific interests are related to remediation technologies, climate changes and environmental management. She has participated in oil pollution remediation projects at Ventspils Nafta Terminal and has experimental work experience in heavy metal leaching and immobilization studies.

Address: Alberta Str. 10, LV-1010, Riga, Latvia

Phone: +371 28469044

E-mail: anete-k@hotmail.com

Andris Karpovičs (Dr.geol.) is the Assistant Professor at the Faculty of Building and Civil Engineering, Riga Technical University. A. Karpovičs received a Doctoral Degree from the University of Latvia (2010). He is a supervisor of Bachelor and Master Theses. A. Karpovičs is a Member of the Latvian Union of Geologists, Latvian Association for Quaternary Research and Latvian Geotechnical Society.

Address: Azenes Str. 16/20, Riga, LV-1048, Latvia

E-mail: andris.karpovics@gmail.com.

Māris Kḷavin̄š (Professor, Dr.hab.chem.) is the Head of the Department of Environmental Sciences of the Faculty of Geography and Earth Sciences, University of Latvia. M. Klavins has worked as the Head of Laboratory of Sorbents at the Institute of Applied Biochemistry of the Academy of Sciences USSR, Head of Hydrochemistry Group of the Institute of Biology (since 1992 is affiliated with the University of Latvia). M. Kḷavinš is a Member of editorial boards of 6 scientific journals, Member of 3 societies related to environmental chemistry issues and Full Member of the Academy of Sciences of Latvia.

Address: Raina Blvd. 19, LV-1586, Riga, Latvia

E-mail: maris.klavins@lu.lv

\section{Juris Burlakovs, Anete Kārkliṇa, Andris Karpovičs, Māris Kḷaviņš. Māla piedevas svina imobilizācijai piesārṇotās augsnēs}

Vides piesārnojumam un tā ietekmei uz cilvēka veselību mūsdienās ir aizvien lielāka nozīme, tādēḷ pieaug augsnes attîrišanas loma vides rekultivācijas darbu veikšanā. Latvijā ir ap 600 esošo un bijušo militāro teritoriju, dạ̦ā no tām raksturīga smago metālu piesārṇojuma klātbūtne. Rakstā sniegts apskats par Latvijā bieži sastopamo derīgo izrakteņu - devona un kvartāra - mālu modificēšanu, kas ḷauj uzlabot smago metālu sorbcijas īpašības. Kā parastos, arī tā modificētos mālus ar dažādu efektivitāti var praktiski pielietot kā lētu augsnes piedevu, tādējādi būtu iespējams samazināt smago metālu piesārṇojuma izskalošanos apkārtējā vidē no vēsturiski piesārnotajām rūpnieciskajām un militārajām teritorijām. Modifikācija tika veikta eksperimentālā veidā, izmantojot $\mathrm{Ca}$ un $\mathrm{Na}$ sāļus, $\mathrm{KH}_{2} \mathrm{PO}_{4}, \mathrm{FeOOH}$. Eksperimentu cikli tika veikti ar trīs dažādām augsnēm, pievienojot 13 dažādas māla piedevas 10\% apjomā no piesārņotās augsnes masas. Izskalošanas testu rezultāti pierāda, ka modificētu mālu svina imobilizācijas īpašības ievērojami uzlabojas, ja tiek veikta modifikācija ar kalcija, nātrija sāliem, hidroksilapatītu, arī ar dzelzs oksihidroksīdu. Papildus veikts kvantitatīvais eksperiments ar Sātinu mālu - piesārṇojuma imobilizācija augsnē strauji pieaug, palielinot piedevas daudzumu attiecībā pret augsnes masu. Lielauces, Sātinu un Lodes karjeru māls var tikt izmantots kā augsnes piedeva ar metāliem piesārņotās augsnēs, samazinot smago metālu apdraudējumu videi. Tādējādi iespējams ekonomiski izdevīgi izmantot Latvijas bieži sastopamo izrakteni - mālu - rekultivācijas darbu veikšanai.

\section{Юрис Бурлаковс, Анете Карклиня, Андрис Карповичс, Марис Клявиныш. Глины как иммобилизатор свинца в загрязненных почвах}

Влияние загрязнения на окружающую среду и здоровье человека в настоящее время становится все более важным и растет потребность в восстановлении и рекультивации почв. Количество бывших военных объектов в Латвии составляет около 600, часть из них характеризуются наличием загрязнения тяжелыми металлами. Эта статья содержит описание экспериментальных работ по модификации общераспространенных полезных ископаемых Латвии - девонских и четвертичных глин, которые могут улучшить сорбционные свойства почв для иммобилизации тяжелых металлов. Модифицированные глины с различной эффективностью могут быть практически использованы в качестве дешевой добавки в почву, чтобы уменьшить выщелачивание тяжелых металлов в исторически загрязненных промышленных и военных объектах. Модификация была проведена экспериментально с помощью солей кальция, натрия, калиевым дигидрогенным фосфатом и оксигидроксидом железа. Экспериментальные циклы проводились с тремя различными почвами, добавляя 13 различных глин пропорционально $10 \%$ от массы загрязненных почв. Результаты показывают, что глина имеет хорошие иммобилизационные характеристики, особенно варианты ее модификации солями, а также гидроксилапатитом и оксигидроксидом железа. Дополнительно проведены количественные эксперименты с глиной карьера Сатини - иммобилизация загрязнения металлами быстро растет, увеличивая количество добавки для почвенной массы. Глины можно использовать в качестве добавки к почве загрязненной металлами. Таким образом снижается риск тяжелым металлам выщелачиваться в окружающую среду. Это экономически выгодное использование латвийских общераспространенных полезных ископаемых - глин - в рекультивационных работах. 